\title{
Promotion and Tenure Perceptions of University Aviation Association (UAA) Collegiate Aviation Administrators and Faculty: Administration Perceptions versus Faculty Perceptions
}

\author{
Samuel R. Pavel and Bryan T. Harrison \\ Southern Illinois University Carbondale
}

Authors' Note:

Samuel R. Pavel, Department of Aviation Management and Flight, Southern Illinois University Carbondale; Bryan T. Harrison, Department of Aviation Management and Flight, Southern Illinois University Carbondale. Correspondence pertaining to this article may be addressed to Dr. Samuel Pavel, Department of Aviation Management and Flight MC 6623, Southern Illinois University Carbondale, Carbondale, IL 62901; phone: 618.453.7269 email: spavel@ aviation.siu.edu.

\begin{abstract}
This study compared the perceptions of faculty members and administrators of the value placed on the pillars of tenure, the value of various aviation publications, sole versus multi-authorship, and the geographic venue for presenting scholarly research. The study used a database created from a survey administered by Dr. Ruiz of Southern Illinois University (see Pavel, Legier, and Ruiz, 2012). The database contains responses to 20 multiple-choice questions (with additional comments) of 19 department chairs, 10 full professors, 29 associate professors, and 24 assistant professors from four-year collegiate UAA member institutions. The respondents responses were divided by employment classification and institution type (research versus non-research). The results indicated that there was generally little difference between administration and faculty perceptions to the survey questions at similar institution types. Survey responses differed more when comparing research to non-research institutions, specifically responses on the value of scholarship in the promotion and tenure process. Teaching and service perceptions were generally similar for all groups of respondents.
\end{abstract}

\section{Introduction}

The promotion and tenure process can be a challenging endeavor for new faculty members. The specific policies and procedures vary among institutions. Finding the right balance of the three pillars is imperative to receiving promotion and tenure.

The previous study by Pavel, Legier, and Ruiz (2012) indicated that "perceptions of faculty workload items used to determine fitness for promotion and tenure are not uniform throughout collegiate aviation" (p. 49). The survey they administered indicated that scholarship, teaching, and research were all important to some level but the survey responses differed based on the size of institution. In addition to the survey results their study recommended further study, "comparing the perceptions of administrators versus faculty on the topic of promotion and tenure" (p. 50). Faculty members needing to navigate their individual institutions procedures for promotion and tenure they may receive conflicting advice from department chairs and other faculty members. 
This study compares the perceptions of faculty members and administrators by reviewing the same database created by the Pavel et al. (2012) study. A comparison of faculty and administration responses of the value placed on the pillars of tenure, the value of various aviation publications, sole versus multi-authorship, and the geographic venue for presenting scholarly research was conducted. For the purposes of this study department chairs are considered to be university administrators since they have more supervisory duties and may have a smaller teaching load than regular faculty.

\section{Literature Review}

In Pavel et al. (2012), the literature review focused on the roots of the promotion and tenure and identified some perceptions of the workload components in the process. In this study, the literature review further explored the development and weight of the workload components, a brief examination of promotion and tenure in three unrelated academic disciplines (counselor educators, information systems, and business), and finally a look at lessons learned from an administration/faculty study from the Recreation and Leisure Studies discipline.

\section{Workload Components in Promotion and Tenure: Comparison Across Disciplines}

A study performed in 2006 by Davis, Levitt, McGlothlin, and Hill evaluated the perceived expectations relating to the promotion and tenure process in the discipline of counselor educators. More specifically, this study was to determine the practices that contribute to decisions in the promotion and tenure process. Seventy-four counseling and related educational programs were assessed in this study. The results from this study indicated that a relatively equal amount of emphasis was placed on scholarship, teaching, and service.

Although the primary purpose of this study was to explore the views of the promotion and tenure process, the secondary purpose was to understand respondent's perceptions on the definition of scholarship according to Boyer's (1990) model. Following the methodology of Emmert and Rollman (1997) in defining workload assignments for an academic year, the authors reported that the results of percent faculty time assigned to scholarship, teaching, and service were relatively (statistically) insignificant for this discipline.

Results from this study recognized that the mean analysis for teaching, scholarship, and service were $M=2.08, M=2.33$, and $M=2.38$, respectively, with a mean faculty teaching assignment load of 4.04 courses per academic year. Further, the respondents were asked to indicate their percentage of time as related to teaching, scholarship, and service. The results indicated that assistant professors spend more time in teaching, than in service or scholarship activities. The authors also identified in this study, that there is a perceived increase in service activities as a faculty member moves from assistant to associate professor. With this identified, the authors urge caution for new faculty members in that service as identified by assignment workload had the least impact on promotion and tenure to the associate professor level. The final survey questions of this 
study asked respondents to indicate their support for Boyer's (1990) model. Respondents to this study strongly endorsed Boyer's model integration to this discipline with a mean score of $M=3.64$ out of 4.0 on a Lickert-type scale.

Dennis, Valacich, Fuller, and Schneider (2006) additionally evaluated the standards for promotion and tenure in the discipline of Information Systems (IS). The authors presented the following question in their study. "...... what constitutes appropriate research standards for tenure and promotion in the IS profession?" (p. 2). With the overall purpose of this study to provide a set of benchmarks that can be used for establishing standards in the promotion and tenure decision making process, the authors further based this study on defining "elite journals" for publication in the IS discipline, stating that journal publications are a principal consideration in the promotion and tenure process.

The authors state that teaching and service often have clear standards established by local institutions, but in the judging of research performance, the quality and quantity of publications is a difficult task. To define an elite level of journals, the authors followed the approach prepared by Trieschmann, Dennis, Northcraft, and Niemi (2000) in which journals were perceived as being "good quality" or "beyond reproach." This methodology led to the development of a listing of two IS journals and 18 additional cross-disciplinary business journals. This analysis provides a recommendation of journals for the IS discipline and increased quality of publications.

An additional underlying purpose identified in this study was to educate and encourage faculty members making promotion and tenure decisions of the need to understand the levels of publication and the need for individuals to increase the number of publications in elite journals. Further the authors called on colleagues writing external letters to use the recommendations of this study and the journals identified in evaluating research performance during the promotion and tenure process. The bottom-line argument in this study was that the promotion and tenure decision making process in the IS discipline requires re-evaluation. As the authors argued, teaching and service are more clearly defined measures in the process. What is not presently clear in the promotion and tenure merits in the IS discipline, is a measure or "benchmark" of what a quality or "elite" publication is. Therefore, this study tried to provide a more defined understanding as to which journals, quality research can be published. With only two discipline-specific journals available for publication to this discipline at the time of this study (Information Systems Research and MIS Quarterly), the authors efforts to show that cross-discipline quality publishing requires re-examination by those that are making promotion and tenure decisions in the IS profession.

A two-year longitudinal study performed by Lein and Merz (1978) from 1977 through 1978 evaluated faculty evaluations concerning required activities for promotion and tenure. This study found that in institutions that achieve accreditation through the Association to Advance Collegiate Schools of Business (AACSB) - accredited schools weighted teaching at $39 \%$, research at $40 \%$, and service at $21 \%$. Accordingly, nonaccredited AACSB schools weighted teaching at 56\%, research at $19 \%$, and service at $25 \%$. As reported in the study, though service is traditionally one of the three components relating to decisions in promotion and tenure, non-accredited AACSB schools identified 
service as a higher importance than research. For AACSB accredited schools, teaching and research were statistically measured at the same level or weight, but the authors argue there is still an inconsistency, dependent on this study (accreditation vs. nonaccreditation), as to the focus of the type of institution in their decisions during the promotion and tenure decision making process.

Saunders, Luchs, and Smith (2006) investigated the perceived importance of service in promotion and tenure decisions. The authors argue that even at the time of this inquiry, why is the definition of service so vague? Of the three major merits in the promotion and tenure process, service is one of the three. The authors distributed a survey $(N=1,335)$ consisting of two series of statements relating to the perceived importance of service in the promotion and tenure process and how important should service be. The questions were also divided into sub-questions relating to two responses, 1) promotion and 2) tenure. The survey questions were rated on a 5-point type Lickert scale from 1-not important to 5-very important. The mid-scale of 3 related to a response of moderately important. Subjects for this survey were drawn from nation-wide faculty who were listed in the Hasselback directory. Additionally, the authors requested demographic information pertaining to the size of the institution from which respondents were submitting the survey. They found that $39 \%$ of all respondents worked in an institution in the "small school" category (less than or equal to 5,000 FTE), 30\% of the respondents were associated with the "medium" category (5,001 to 10,000 FTE), and $31 \%$ of the respondents responded from the "large" category (more than 10,001 FTE).

Results $(n=147)$ from the survey identified that for the decision to promote faculty to the position of associate professor, the $M=2.44$ or "slightly" to "moderately important." Additionally, the results found that the decision to grant tenure also had a $M=2.44$. The authors believed that the agreement in mean scores between these two questions is based on the fact that many institutions combine promotion and tenure in same decision making process. Further, results for decision to promote to full professor yielded a $M=2.92$, again, rated at the "moderately important" level.

Based on further comparison of the size of the institutions and survey results, the authors state that the overall results indicated that the performance of service is not consistent among institutions for promotion and tenure decisions. The results of the survey identified "service" as only "slightly important" to "moderately important" in decisions to achieve the level of associate professor, with a slightly higher result of "moderately important" for achieving the level of full professor. The authors furthermore stated that small and medium size institutions place a higher emphasis on service, than larger schools. Also, institutions without $\mathrm{PhD}$ programs value service more than those institutions with $\mathrm{PhD}$ programs.

Administration Versus Faculty Perceptions: Lessons Learned From the Recreation and Leisure Studies Discipline

In a special report on Faculty Promotion and Tenure: Eight Ways to Improve the Tenure Review Process at Your Institution, Cipriano and Riccardi (2009) reported the performance of two national studies on recreation department chairs and full-time faculty 
members in the recreation and leisure studies discipline. The purpose of these studies was to have the respondent's rank the most important factors leading to the awarding of promotion, tenure, and reappointment. In both the 2004 and 2006 studies, both chairs and faculty listed as the top three factors in considering promotion and tenure as: a) teaching, b) research, and c) publications.

The first of the studies (2004) consisted of 17 factors to be considered by department chairs and directors during the promotion and tenure selection process. Along with factors relating to scholarship, teaching, and service, other factors (not all inclusive) in the survey identified areas such as: a) student advisement, b) time spent on campus, c) consultation, d) use of technology, and e) supervision of independent studies. The authors found from the rankings, that $50 \%$ of the chairs in this study listed teaching (99\%), publications $(86 \%)$, and research $(85 \%)$ as the top three ranked major factors in personnel decisions when considering faculty for promotion and tenure. What was further noted by the authors in this study was that none of the other 14 factors were ranked at a greater than 50\% agreement by the responding chairs. In their 2006 study, the results found that five factors were listed as major factors by more than $50 \%$ of the respondents. This included: a) teaching $(95 \%)$, b) publications $(81 \%)$, c) research $(79 \%)$, d) service to the department (55\%), and e) grants submitted (50\%).

Further, the 2006 study included faculty members and the number of survey factors included increased from 17 to 21. The purpose of adding more factors was based on identifying faculty's perceptions in achieving tenure, promotion, and/or reappointment. Results from the faculty responses showed that they identified eight major factors to be considered for tenure. These included: a) teaching (95\%), b) research $(73 \%)$, c) publications $(68 \%), \mathrm{d})$ interaction with students $(61 \%)$, e) evidence of student learning $(59 \%), \mathrm{f})$ service to the department $(55 \%), \mathrm{g})$ interpersonal attributes/collegiality (54\%), and h) grants submitted (52\%).

Cipriano and Riccardi conclude "....it is clear that faculty perceive that there is more for them to do than their department chairs" (p. 10) based on the comparison of chair and faculty perceptions in the decision process of tenure and promotion. Further, the authors raised the question, what are the implications for the potential disconnect between chair decisions and those perceived by faculty in achieving tenure and promotion?

\section{Summary Thoughts}

Evident from the studies and literature provided above, there is still an inconsistency amongst discipline-specific, departments/units, institutions, and further, academe on what are the requirements for achieving promotion and tenure. A sample to the open-ended responses to questions on the relationship between attitudes toward promotion and tenure presented by Diamantes's (2004) research through a survey to the members of the National Council of Professors of Educational Administration (NCPEA) and Association/Advancement of Educational Research (AARE) should awaken those in the promotion and tenure (decision-making) process: 
- Promotion and tenure are supposed to be based on a combination of teaching, research, and service, but in fact they appear to be based solely (or at least primarily) on research that has little relation to reality.

- Definitions exist, but the P\&T committee's presentations obfuscate the definitions. For example, one tenured faculty member said to group of non-tenured teachers that, "This is a club and acceptance to it is getting more difficult.

- The tenure and promotion process should not be a mystery. As we work with folks who are on tenure track, we should offer support and guidance and give them on-going feedback as to whether or not they are making appropriate progress (Diamantes, 2004, pp. 6 - 7).

\section{Method}

This study used the same database developed from a survey developed by Dr. Ruiz of Southern Illinois University Carbondale. For a complete description of the survey and supporting materials see Pavel et al. (2012). The data did not allow for reporting responses of administration and faculty by institution size because of the limited number of responses from persons identified as administration. However, slightly more than half of the administrator responses came from institutions classified as Research Universities. Slightly over 58\% of the responses from faculty were from institutions classified as Research Universities. Therefore the data was categorized as either Administration or Faculty and when appropriate subcategorized as "research" or "non-research." Means, frequencies, and standard deviations were calculated and used to analyze information in the database.

\section{Results}

\section{Three Pillars of Tenure}

Each participant in the survey was asked to rank their perception of the standard three "pillars" of promotion and tenure (scholarship, teaching, and service) on the following scale: Not Important $=1$; Minimally Important $=2$; Somewhat Important $=3$; Important $=$ 4 ; Very Important $=5$. The results are presented in Table 1 . The smallest number of survey respondents were Full Professors, of which only three were from non-research institutions. Therefore Full Professors results were not differentiated between research and non-research. Interestingly, all three Full Professors from non-research institutions ranked scholarship and teaching as Very Important (5) for tenure and/or promotion.

In the aggregate, faculty and administration rated service as the least important of the three pillars. However, when broken down into the subcategory of research and nonresearch institutions a different result appears. Each group in the non-research subcategory ranked service above scholarship. Whereas, all groups in the research subcategory and the full professor group ranked scholarship as the most important pillar. All groups in the non-research subcategory ranked teaching as the most important pillar. 
Specific questions about each pillar were asked to get more detail about the perception of each pillar. The results are presented in the next three sections.

Scholarship. A majority (61\%) of all survey respondents "Strongly Agree" or "Agree" when asked if scholarship is a critical gauge in determining an individual's fitness for promotion and/or tenure. However, the proportion of those who "Strongly Agree" or "Agree" falls when the survey respondents are separated into research and non-research subgroups. For the non-research subgroup the proportion that "Strongly Agree" or "Agree" falls to $38 \%$ (Table 2).

Scholarly activity venues. Survey respondents were asked to rank venues of scholarly activity on the same five-number scale used above: Not Important $=1$; Minimally Important $=2$; Somewhat Important $=3$; Important $=4$; Very Important $=5$. The results are presented in Table 3.

The highest rated scholarly venue by both administration and faculty was publishing a peer-reviewed journal article. The faculty ranked receiving an external grant and publishing a book as comparable with the peer-reviewed journal article. The only other venue the faculty ranked above "Important" was publishing a chapter in a book. Administration survey respondents agreed with the faculty that publishing a book was comparable to a peer-reviewed journal article, but did not rank receiving an external grant or publishing a chapter in a book above "Important." The lowest ranked venues by both faculty and administration were any non-peer-reviewed venue.

Table 1

Perceived Importance of the Three Standard Pillars of Promotion and Tenure

\begin{tabular}{lccc}
\hline & Scholarship & Teaching & Service \\
\cline { 2 - 4 } Employment and Institution Classification & $M(S D)$ & $M(S D)$ & $M(S D)$ \\
\hline Administration - research & $4.80(0.63)$ & $3.70(1.55)$ & $2.80(1.33)$ \\
Administration - non-research & $2.75(1.58)$ & $4.63(0.70)$ & $3.25(0.83)$ \\
All Administration & $3.89(1.53)$ & $4.11(1.37)$ & $3.00(1.19)$ \\
Full Professor & $4.80(0.63)$ & $4.60(0.97)$ & $3.70(1.16)$ \\
Associate Professor - research & $4.75(0.72)$ & $4.05(0.89)$ & $3.05(1.10)$ \\
Associate Professor - non-research & $4.00(1.00)$ & $4.78(0.44)$ & $4.11(1.05)$ \\
Assistant Professor - research & $4.27(1.27)$ & $3.73(1.49)$ & $3.09(1.14)$ \\
Assistant Professor - non-research & $3.38(0.96)$ & $4.69(0.85)$ & $3.77(1.09)$ \\
All Faculty & $4.31(1.01)$ & $4.29(1.04)$ & $3.43(1.12)$ \\
\hline
\end{tabular}


Table 2

Scholarship is a critical gauge in determining an individual's fitness for promotion and/or tenure

\begin{tabular}{|c|c|c|c|c|c|}
\hline Employment Classification & $\begin{array}{c}\text { Strongly } \\
\text { Agree }\end{array}$ & Agree & Disagree & $\begin{array}{l}\text { Strongly } \\
\text { Disagree }\end{array}$ & Neither \\
\hline Administration - research & 5 & 3 & 2 & 0 & 0 \\
\hline Administration - non-research & 0 & 5 & 2 & 1 & 1 \\
\hline Faculty - research & 11 & 22 & 5 & 2 & 3 \\
\hline Faculty - non-research & 3 & 4 & 7 & 4 & 7 \\
\hline
\end{tabular}

Aviation publications. Survey respondents were asked to rank specific aviation publications on the five-number scale: Not Important $=1$; Minimally Important $=2$; Somewhat Important $=3$; Important $=4$; Very Important $=5$. The results are presented in Table 4. There was very little difference between the responses of faculty at all ranks from research and non-research institutions. Therefore the faculty scores are aggregated. The administration responses were different based on if the administrator was from a research or non-research institution.

Table 3

Perceived Value of Scholarly Activity Venue

\begin{tabular}{llc}
\hline \multicolumn{1}{c}{ Publishing Venues } & Administration & Faculty \\
& \multicolumn{2}{c}{$M(S D)$} \\
\hline Peer-Reviewed Journal Article & $4.61(0.85)$ & $4.66(0.68)$ \\
Externally Funded Grant & $3.76(1.48)$ & $4.62(0.62)$ \\
Publishing a Book & $4.56(1.15)$ & $4.60(0.63)$ \\
Publishing a Chapter in a Book & $3.89(1.13)$ & $4.04(0.82)$ \\
Peer-Reviewed Abstract, Conference & $3.44(1.15)$ & $3.71(0.93)$ \\
$\quad$ & & \\
$\quad$ Proceedings, etc. & $3.18(1.24)$ & $3.68(0.84)$ \\
Conference/ Professional Presentation & $2.82(1.19)$ & $3.50(0.91)$ \\
Internally Funded Grant & $3.50(1.25)$ & $3.49(0.80)$ \\
Member of Peer-Reviewed Journal Panel & $2.67(0.97)$ & $2.76(0.95)$ \\
Consultantship & $2.61(1.24)$ & $2.74(0.92)$ \\
Research Posters & $2.61(1.33)$ & $2.68(1.10)$ \\
Aviation Trade Magazine Article & $2.59(1.18)$ & $2.67(0.93)$ \\
Book Review & $2.44(0.78)$ & $2.60(0.87)$ \\
Non Peer-Reviewed Abstract, & & \\
$\quad$ Conference Proceedings, etc. & $2.44(0.86)$ & $2.49(0.87)$ \\
Non Peer-Reviewed Journal Article & & \\
\hline
\end{tabular}


Administration from non-research institutions were fairly consistent ranking all publication venues as "Somewhat Important" and "Minimally Important." There also was a wide variation in their rankings of the publications with no standard deviation below 1.00. There is agreement between the faculty and the administration from research institutions. They all rated six publications above "Important," and also agreed that publishing in an aviation trade magazine or publishing in a non-peer-reviewed journal was "Minimally Important."

When asked about the value of single-author verses multi-authored publications the administrator tended to see more value in single-author publications. Faculty were split between a single-author publication being more valuable and single-author and multiauthor publication being of equal value (Table 5).

However, being lead author in a multi-publication was deemed more valuable by every group except faculty at non-research institutions, which were split between equal and more valuable (Table 6).

When asked if authors were asked to report the percentage of individual effort/contributions in a multi-author publication, most replied "No" (Table 7).

Table 4

Perceived Value of Aviation Publication

\begin{tabular}{lccc}
\hline & \multicolumn{2}{c}{ Employment Classification } \\
\cline { 2 - 3 } & \multicolumn{2}{c}{ Administration } & \\
\cline { 2 - 3 } \multicolumn{1}{c}{ Publication Name } & Research & Non-research & Faculty \\
& $M(S D)$ & $M(S D)$ & $M(S D)$ \\
\hline Collegiate Aviation Review & $4.50(0.81)$ & $3.44(1.26)$ & $4.46(0.70)$ \\
International Journal of Applied Aviation Studies & $4.30(0.90)$ & $3.44(1.77)$ & $4.42(0.77)$ \\
Journal of Air Transportation & $4.50(0.81)$ & $3.56(1.71)$ & $4.40(0.70)$ \\
Journal of Aviation/ Aerospace Education and & $4.70(0.64)$ & $3.44(1.77)$ & $4.39(0.76)$ \\
$\quad$ & & & \\
$\quad$ Research & $4.70(.064)$ & $3.44(1.77)$ & $4.39(0.76)$ \\
Journal of Aviation Management and Education & $4.50(0.67)$ & $3.56(1.71)$ & $4.17(0.86)$ \\
International Journal of Professional Aviation & & & \\
$\quad$ Training and Testing Research & & $3.85(1.18)$ \\
The International Journal of Safety Across High- & $3.90(1.22)$ & $3.44(1.77)$ & 3.85 \\
$\quad$ Consequence Industries & & & \\
Academic and Business Research Institution & $3.67(1.41)$ & $2.89(1.37)$ & $3.44(1.08)$ \\
American Technical Education Association & $3.22(1.40)$ & $2.89(1.37)$ & $3.44(1.11)$ \\
Aviation Trade Magazine Article & $2.56(1.26)$ & $2.89(1.29)$ & $2.88(1.15)$ \\
Non Peer-Reviewed Journal Publications & $2.20(0.98)$ & $2.56(1.07)$ & $2.48(0.99)$ \\
\hline
\end{tabular}




\section{Table 5}

Do you consider a single-author publication more valuable than a multi-author publication in achieving promotion and/or tenure?

\begin{tabular}{lcccc}
\hline & Yes & No & $\begin{array}{c}\text { Single and Multiple } \\
\text { Author Equal }\end{array}$ & Don't know \\
\hline Employment Classification & 7 & 1 & 2 & 0 \\
Administration - research & 5 & 1 & 2 & 1 \\
Faculty - research & 21 & 2 & 15 & 0 \\
Faculty - non-research & 10 & 3 & 17 & 0 \\
\hline
\end{tabular}

\section{Table 6}

Do you believe that being identified as the first author in a multi-author publication is more valuable than other authorships in achieving promotion and/or tenure?

\begin{tabular}{lcccc}
\hline Employment Classification & Yes & No & $\begin{array}{c}\text { All Authorships } \\
\text { Possess Equal Value }\end{array}$ & Don't know \\
\hline Administration - research & 8 & 1 & 1 & 0 \\
Administration - non-research & 3 & 3 & 2 & 1 \\
Faculty - research & 32 & 2 & 4 & 0 \\
Faculty - non-research & 10 & 5 & 12 & 3 \\
\hline
\end{tabular}

Table 7

Are authors in multi-author publication required to report percentages of individual effort/contribution made in the development of the publication during the promotion and/or tenure process?

\begin{tabular}{lccc}
\hline Employment Classification & Yes & No & Don't know \\
\hline Administration - research & 3 & 6 & 1 \\
Administration - non-research & 0 & 8 & 1 \\
Faculty - research & 11 & 22 & 5 \\
Faculty - non-research & 3 & 18 & 9 \\
\hline
\end{tabular}

The last area surveyed in the area of scholarship was the perceived value of scholarly activity in various geographical venues (Table 8). Again the faculty from research and non-research institutions were similar and thus aggregated. The administration from research and non-research were again dissimilar in every geographical venue except Local. However, the variation in the responses in once again large.

Teaching. Almost all survey respondents consider teaching to be a critical gauge in determining an individual's fitness for promotion and/or tenure. Over $87 \%$ of the survey respondents from both research and non-research institutions either "Strongly Agree" or "Agree" when asked about the importance or teaching (Table 9). 
Table 8

Perceived value of scholarship activity in geographical venues toward successfully achieving promotion and/or tenure.

\begin{tabular}{cccccc}
\hline $\begin{array}{c}\text { Employment } \\
\text { Classification }\end{array}$ & $\begin{array}{c}\text { International } \\
M(S D)\end{array}$ & $\begin{array}{c}\text { Local } \\
M(S D)\end{array}$ & $\begin{array}{c}\text { National } \\
M(S D)\end{array}$ & $\begin{array}{c}\text { Regional } \\
M(S D)\end{array}$ & $\begin{array}{c}\text { State } \\
M(S D)\end{array}$ \\
\hline Administration & & & & & \\
$\quad$ research & $4.80(0.60)$ & $3.20(1.40)$ & $4.50(0.81)$ & $4.20(0.75)$ & $3.90(0.83)$ \\
$\quad$ non-research & $3.67(1.70)$ & $3.22(1.13)$ & $3.89(1.45)$ & $3.78(1.31)$ & $3.67(1.33)$ \\
Faculty & $4.32(1.07)$ & $3.03(1.04)$ & $4.46(0.76)$ & $3.76(0.85)$ & $3.44(0.92)$ \\
\hline
\end{tabular}

Table 9

Teaching performance is a critical gauge in determining an individual's fitness for promotion and/or tenure.

\begin{tabular}{lccccc}
\hline Employment Classification & $\begin{array}{c}\text { Strongly } \\
\text { Agree }\end{array}$ & Agree & Disagree & $\begin{array}{c}\text { Strongly } \\
\text { Disagree }\end{array}$ & Neither \\
\hline Administration - research & 4 & 3 & 1 & 2 & 0 \\
Administration - non-research & 4 & 3 & 0 & 2 & 0 \\
Faculty - research & 19 & 11 & 0 & 0 & 1 \\
Faculty - non-research & 15 & 16 & 1 & 2 & 2 \\
\hline
\end{tabular}

However, when asked if the evaluation of teaching was fair and accurate only one administrator and faculty (both from a research institution) "Strongly Agree." Almost $59 \%$ of the survey respondents responded with something other than "Strongly Agree" or "Agree." Almost 13\% "Strongly Disagree" that teaching evaluation is fair and accurate (Table 10).

Table 10

The methods used for evaluating classroom instruction at my institution are fair and accurate.

\begin{tabular}{lccccc}
\hline Employment Classification & $\begin{array}{c}\text { Strongly } \\
\text { Agree }\end{array}$ & Agree & Disagree & $\begin{array}{c}\text { Strongly } \\
\text { Disagree }\end{array}$ & Neither \\
\hline Administration - research & 1 & 3 & 3 & 2 & 1 \\
Administration - non-research & 0 & 6 & 0 & 1 & 2 \\
Faculty - research & 1 & 15 & 12 & 4 & 6 \\
Faculty - non-research & 0 & 10 & 10 & 4 & 6 \\
\hline
\end{tabular}

Almost all survey participants responded that students evaluate classroom instruction. Administration responded that peers/faculty evaluate classroom performance more than $67 \%$ of the time. While faculty responded that peers/faculty only evaluate classroom instruction at non-research institutions $57 \%$ of the time and only $37 \%$ at research institutions. The chairperson most likely did not evaluate classroom instruction at research institutions (Table 11). 
Service. Although the service pillar of tenure was rated the lowest of the three pillars of tenure by administration and faculty, most still agree the pillar is critical in determining an individual's fitness for promotion and/or tenure. Service was divided into three categories: professional, university/institutional, and community. The responses are presented in Tables 12, 13, and 14.

Table 11

How classroom instruction is evaluated?

\begin{tabular}{lcccccc}
\hline \multirow{2}{*}{ Employment Classification } & \multicolumn{2}{c}{ Students } & \multicolumn{2}{c}{ Peers/Faculty } & \multicolumn{2}{c}{ Chairperson } \\
& Yes & No & Yes & No & Yes & No \\
\hline Administration - research & 10 & 0 & 7 & 3 & 2 & 8 \\
Administration - non-research & 6 & 3 & 6 & 3 & 5 & 4 \\
Faculty - research & 36 & 2 & 14 & 24 & 8 & 30 \\
Faculty - non-research & 26 & 4 & 17 & 13 & 13 & 17 \\
\hline
\end{tabular}

Table 12

Professional service is a critical gauge in determining an individual's fitness for promotion and/or tenure.

\begin{tabular}{lccccc}
\hline Employment Classification & $\begin{array}{c}\text { Strongly } \\
\text { Agree }\end{array}$ & Agree & Disagree & $\begin{array}{c}\text { Strongly } \\
\text { Disagree }\end{array}$ & Neither \\
\hline Administration - research & 1 & 7 & 1 & 1 & 0 \\
Administration - non-research & 1 & 5 & 0 & 1 & 2 \\
Faculty - research & 5 & 21 & 3 & 0 & 9 \\
Faculty - non-research & 1 & 18 & 3 & 1 & 7 \\
\hline
\end{tabular}

Professional service was ranked as most important of the three categories of service. Approximately 69\% of the survey respondents either "Strongly Agree" or "Agree" that professional service is a critical factor to gauging and individual's fitness for promotion and/or tenure. However, less than 10\% "Strongly Agree," while over 10\% either "Disagree" or "Strongly Disagree."

Table 13

University/institutional service is a critical gauge in determining an individual's fitness for promotion and/or tenure.

\begin{tabular}{lcccccc}
\hline Employment Classification & $\begin{array}{c}\text { Strongly } \\
\text { Agree }\end{array}$ & Agree & Disagree & $\begin{array}{c}\text { Strongly } \\
\text { Disagree }\end{array}$ & Neither \\
\hline Administration - research & 0 & 6 & 1 & 2 & 1 \\
Administration - non-research & 1 & 5 & 0 & 1 & 2 \\
Faculty - research & 1 & 21 & 8 & 0 & 8 \\
Faculty - non-research & 5 & 17 & 2 & 1 & 5 \\
\hline
\end{tabular}

There was less support for university/institutional service than professional service. Only 64\% of survey responses were either "Strongly Agree" or "Agree." 
Table 14

Community service is a critical gauge in determining an individual's fitness for promotion and/or tenure.

\begin{tabular}{lccccc}
\hline Employment Classification & $\begin{array}{c}\text { Strongly } \\
\text { Agree }\end{array}$ & Agree & Disagree & $\begin{array}{c}\text { Strongly } \\
\text { Disagree }\end{array}$ & Neither \\
\hline Administration - research & 1 & 2 & 1 & 1 & 5 \\
Administration - non-research & 0 & 5 & 0 & 1 & 3 \\
Faculty - research & 3 & 15 & 13 & 1 & 6 \\
Faculty - non-research & 0 & 11 & 7 & 3 & 9 \\
\hline
\end{tabular}

Community service was the least valued of the types of service. Less than $44 \%$ of the responses were either "Strongly Agree" or "Agree" that community service is a critical factor for gauging an individual's fitness for promotion and/or tenure. Almost one third of the survey respondents answered "Disagree" or "Strongly Disagree."

Progress and/or reviews. The final question in the survey asked if probationary faculty members received annual promotion and tenure progress reports and/or reviews. The responses are presented in Table 15.

Table 15

Probationary (tenure track) faculty members at my institution receive annual promotion and tenure progress and/or reviews.

\begin{tabular}{cccc}
\hline Employment Classification & Yes & No & Don't know \\
\hline Administration - research & 8 & 0 & 2 \\
Administration - non-research & 5 & 4 & 0 \\
Faculty - research & 28 & 7 & 3 \\
Faculty - non-research & 16 & 11 & 3 \\
\hline
\end{tabular}

Over $70 \%$ of the administration and faculty at research institutions responded that probationary faculty are given some sort of annual promotion and tenure review and/or report. In non-research institutions the reported number falls to below $55 \%$.

\section{Discussion}

In the previous paper reporting the perceptions of promotion and/or tenure of the aggregated administration and faculty of UAA institutions (Pavel, Legier, \& Ruiz, 2012) the data indicated that the size of the institutions was an important factor in determining the importance level of the so-called three pillars of tenure and promotion - scholarship, teaching, and service. In this paper we find administration status, faculty rank, and the research classification of the institution also matter. 
In the aggregate administration rated teaching $(M=4.11)$ higher than scholarship (M = 3.89). However administration from research institutions rated scholarship by far the highest $(M=4.80)$, as well did full professors from both research and non-research institutions $(M=4.80)$. Service was rated lowest by all categories, except administration from non-research institutions $(M=3.25)$ and assistant professors from non-research institutions $(M=3.43)$.

The overall trend shows that scholarship and teaching are the important pillars for promotion and/or tenure with service being viewed as somewhat important. Each pillar will now be discussed separately.

Scholarship. Whether or not scholarship was viewed as a critical factor in determining an individual's fitness for promotion and/or tenure appears to depend on the research classification of the institution. Administration and faculty from research institutions tended to view scholarship as critical to the determination. Administration and faculty from non-research institutions viewed scholarship as less critical to the determination, although three of the faculty members strongly agreed scholarship was critical.

When asked about publication venues for scholarship there is considerable agreement between administration and faculty from both research and non-research institutions. The most important publication venue for both administration and faculty was the peerreviewed journal article $(M=4.61$ and $M=4.66$ respectively). Faculty also rated externally funded grant, publishing a book, and publishing a chapter in a book as important $(M>4.00)$. Administration agree that publishing a book was important, but rated externally funded grant and publishing a chapter in a book as somewhat important (3.00<M<4.00). The least important venue for all was non peer-reviewed publications that were ranked minimally important $(2.00<M<3.00)$.

There were differences between administration and faculty when asked about the importance of specific aviation publications. Administration from research institutions and faculty agree that six publications were important for promotion and/or tenure Collegiate Aviation Review, Journal of Air Transportation, International Journal of Applied Aviation Studies, Journal of Aviation/Aerospace Education and Research, Journal of Aviation Management Education, and International Journal of Professional Aviation Training and Testing Research. Administration from non-research institutions did not rank any specific aviation publication as important. Which is consistent with their overall view of scholarship in the tenure and promotion process. The one area of agreement however, was every group agreed that an aviation trade magazine article and non-peer-reviewed journal publication were minimally important.

When asked if a single author publication is more valuable than a multi-author publication, administration from both research and non-research institutions said yes (70\% and 56\% respectively). The faculty yes response was considerably less (56\% and $33 \%$ respectively). Forty-six percent of the faculty tended to view single and multiple authored publications as equal. 
Being identified as lead author in a multi-author publication is viewed as more valuable by all groups, except faculty from non-research institutions. Seventy five percent of all administration and faculty from research institutions stated that being lead author is more important. Only $33 \%$ of faculty from non-research institutions felt that being lead author was more important, with $40 \%$ of the group stating that all authorships possess equal value. Even though being identified as lead author is viewed favorably, only $20 \%$ of all respondents stated that the percentage of individual effort/contribution to the multi-authored publication was required by their institution.

The last question about scholarship in the survey was the importance of the geographic venue of publication. Administration from non-research institutions did not rank any geography venue as important. Their highest ranking was the national venue $(M$ = 3.89). Faculty ranked national and international publication venues as important $(\mathrm{M}=$ 4.46 and 4.32 respectively). Administration from research institutions also ranked international and nation publication venues as important $(M=4.80$ and 4.50 respectively), and also included regional publication venues as important $(M=4.20)$. All groups rated local publication venues the lowest as somewhat important.

Teaching. Teaching was the pillar that largest majority of all groups considered critical to gauging an individual's fitness from promotion and/or tenure. Over $87 \%$ of all survey respondents answered "Strongly Agree" or "Agree" when asked if teaching was critical to the process. Even as important as teaching is, fair and accurate evaluation of teaching appears to be lacking. Only two of all the survey respondents answered "Strongly Agree" when asked if teaching evaluation was fair and accurate. Over $41 \%$ either "Disagreed" or "Strongly Disagree" that teaching evaluation was fair and accurate, which identifies an interesting contradiction. How can teaching be so important to the promotion and tenure process, but teaching evaluation not be fair and accurate?

Perhaps the view that teaching is not as fair and accurate as it could be is because of who is doing the teaching evaluation. The far majority of survey respondents reported that students evaluate classroom instruction. However, slightly over half of the respondents reported that a peer or faculty member evaluated classroom instruction, and less than one-third of the classroom evaluation is done by the chairperson. It appears that classroom evaluation is primarily in the hands of students, who are probably least equipped to evaluate classroom instruction.

Service. Even though service is rated the lowest of the three pillars of promotion and/or tenure, service is still considered critical to determining the fitness of an individual for promotion and/or tenure. The importance of service to the promotion and/or tenure process was separated into three areas - professional service, university/institutional service, and community service. A generic category of service was not included in the survey.

Of the three areas of service, professional and university/institutional service were viewed as the most critical. Sixty-nine percent of the survey respondents either "Strongly Agree" or "Agree" that professional service was critical for promotion and/or tenure. The 
number for university/institutional service was $64 \%$. Community service was viewed by the least number as critical, with only 44\% "Strongly Agree" or "Agree".

Tenure Progress and/or Reviews. The last question on the survey asked if probationary faculty received annual progress and/or reviews. There were a surprising number of survey responses indicating that no such review was given at their institution. Over $18 \%$ of the faculty at research institutions stated that no annual progress and/or review were made. However, all of the administration from research institutions reported that annual progress and/or reviews were made at their institutions. This discrepancy could be explained because not all UAA research institutions are represented in the responses. Over one-third of the administration and faculty at non-research institutions reported that no annual progress and/or review was given to probationary faculty. For probationary faculty member at one of the institutions that do not provide annual reviews, this would seem to be an obstacle to a probationary faculty's progress to promotion and/or tenure. How can progress be made in a deficient area if there is no regular evaluation of faculty performance?

\section{Summary and Conclusion}

This study indicates that there are some perceptual differences between faculty and administrators, but the responses were more aligned by type of institution (research versus non-research) than by employment classification. For example, scholarship was indicated as more critical for promotion and tenure determinations by research institutions than non-research institutions. All groups indicated that teaching was critical to tenure and/or promotion. One concern raised by this survey is that $41 \%$ of respondents indicated that fair and accurate evaluation of teaching was an issue. Student evaluation is the most frequent method of classroom evaluation. Chairperson evaluation is the least frequent method of classroom evaluation. Fewer respondents considered service as critical a pillar as scholarship and teaching. Professional service was the most valued while community service was valued least.

What is clear about the promotion and tenure process in collegiate aviation is there is nothing clear about the promotion and tenure process across all of collegiate aviation. This, and the previous study, do highlight some interesting trends. Larger research institutions will tend to value scholarship over teaching and service. However, all three

are critical to achieve promotion and/or tenure. Smaller non-research institutions tend to value service and teaching and are less likely to have annual progress and/or reviews. The best advice the authors can give when it comes to promotion and/or tenure is, find out which pillars are most important to your institution and excel in all three. 


\section{References}

Boyer, E. (1990). Scholarship reconsidered: Priorities of the professoriate. Princeton, NJ: Carnegie Foundation for the Advancement of Teaching

Cipriano, B., \& Riccardi, R. (2009). Faculty expectations regarding personnel decisions. Special report: Faculty promotion and tenure: Eight ways to improve the tenure review process at your institution. Retrieved from http://www.facultyfocus.com/free-reports/faculty-promotion-and-tenure/

Davis, T. E., Levitt, D. H., McGlothlin, J. M., Hill, N. R. (2006). Perceived expectations related to promotion and tenure: A national survey of CACREP program liaisons. Counselor Education \& Supervision, 46, 146 - 156.

Dennis, A. R., Valacich, J.S., Fuller, M. A., \& Schneider, C. (2006). Research standards for promotion and tenure in information systems. MIS Quarterly, 30(1), 1 - 34.

Diamantes, T. (2004). Online survey research of faculty attitudes toward promotion and tenure. Retrieved from http://www.usca.edu/essays/vol122004/diamantes.pdf

Emmert, P., \& Rollman, S. A. (1997). A national survey of tenure and promotion standards in communication departments. Journal of the Association for Communication Administration, 1, 10-23.

Lein, C. D., \& Merz, C. M. (1978, Winter). Faculty evaluation in schools of business: The impact of AACSB accreditation on promotion and tenure decisions. Collegiate News and Views, 21(24).

Pavel, S. R., Legier, J. T., \& Ruiz, J. R. (2012). Promotion and tenure perceptions of University Aviation Association (UAA) collegiate aviation administrators and faculty. Collegiate Aviation Review, 30(1), 32-61.

Saunders, G., Luchs, C., \& Smith, W. (2006, April). The role of service in P\&T decisions. Journal of College Teaching \& Learning, 3(4), 51-58.

Trieschmann, J. S., Dennis, A. R., Northcraft, G. B., \& Nemi, A. W. (2000). Serving multiple constituencies in the business school: MBA program versus research performance. Academy of Management Journal, 43(6), 1130-1141. 